\title{
The association Geranio phaei-Urticetum dioicae Hadač et al. (1969) in Central Pomerania
}

\author{
Zbigniew Sobisz
}

Department of Botany and Nature Protection, Pomeranian University, Arciszewskiego 22A, 76-200 Słupsk, Poland, e-mail: sobisz@apsl.edu.pl

\begin{abstract}
Geranio phaei-Urticetum dioicae, a poorly known association of nitrophilous outskirts communities was characterized based on 16 phytosociological relevés. Its ecological requirements and distribution in Pomerania and Poland are presented. A new subassociations of the Geranio phaei-Urticetum dioicae allietosum ursini have been distinguished on the basis of differing species composition. Edaphic and phytocenotic conditions of the population were specified. Association is found in mineral soil of acid reaction abundant with nitrogen and phosphorus, and as to its quantity it belongs to less numerous ones at Pomerania.
\end{abstract}

Key words: Geranium phaeum, nitrophilous outskirts communities, Convolvuletalia sepium, Central Pomerania

\section{Introduction}

The general distribution of Geranio phaei-Urticetum dioicae is not yet identified. Geranium phaeum is diagnostic species of the association with Alpic-CentralEuropean distributional type, occurs in mountain and submontane areas of Europe (Zając \& Zając 2009). In Central Europe this plant association has been recorded rarely. It was described in the Belianské Tatra Montains (Hadač et al. 1969). In the first description of the association Author's included it in the class RuderoSecalietea Br.-B1. 1936, order Onopordetalia acanthii Br.-B1. \& R.Tx. 1943 and alliance Carduo-Urticion dioicae Hadač 1962. This alliance, in his opinion, contained nitrophilous saum communities developing on calcareous soils. The association was reported as quite common in the Austrian Alps and their foothills, especially on calcareous substratum (Mucina 1993). Brzeg (1989) located Geranio phaei-Urticetum dioicae in the class Artemisietea vulgaris Lohmeyer, Preising \& R. Tx. in R. Tx. 1950, order Galio-Calystegalia sepium (R. Tx. 1950) Oberd. 1967, alliance Aegopodion podagrariae R. Tx. 1967 and suballiance MelandrioAegopodienion (R. Tx. 1967) Siss. 1973. According to Ratyńska et al. (2010) the syntaxonomic position of the Geranio phaei-Urticetum dioicae Hadač et al. 1969 is a follow: class Artemisieta vulgaris Lohmeyer et al. in
R. Tx. 1950, order Convolvuletalia sepium R. Tx. 1950 ex Lohmeyer 1953 em Oberd. in Oberd. et al. 1967, alliance Petasition officinalis Silinger 1933.

In Poland, the population of Geranium phaeum was numerous in the past times in the Carpathian and Sudety foreland, in north Małopolska and Lublin Highlands with isolated localities on lowlands (north Poland) (Zając 1996). In Central Pomerania, whose borders are marked conventionally by the River Łeba in the East and the River Parsęta in the West (according to Kondracki 2004) it is an eastern part of Western Pomerania. Geranium phaeum is found at the former manor-park complexes in Boleszewo and Osieki Koszalińskie (Fig. 1). Geranium phaeum stands are situated within the ATPOL grid - (Boleszewo BA87, Osieki Koszalińskie BA94) following the principles adopted for the "Atlas of the Distribution of the Vascular Plants in Poland" (Zając 1978). Boleszewo is a small village within the premises of Sławno Commune and Osieki Koszalińskie the premises of Sianów Commune in Pomeranian Province. According to a geobotanical division of Poland (Matuszkiewicz 1993), the villages belonging to the Słupsk Region included within the area of the Southern Baltic Coastland and Pomeranian Divide. According to a physical-geographical division of Poland (Kondracki 2004), Boleszewo is situated within the mesoregion of the Sławno Plain and Osieki Koszalińskie - Słowińskie Coast. 


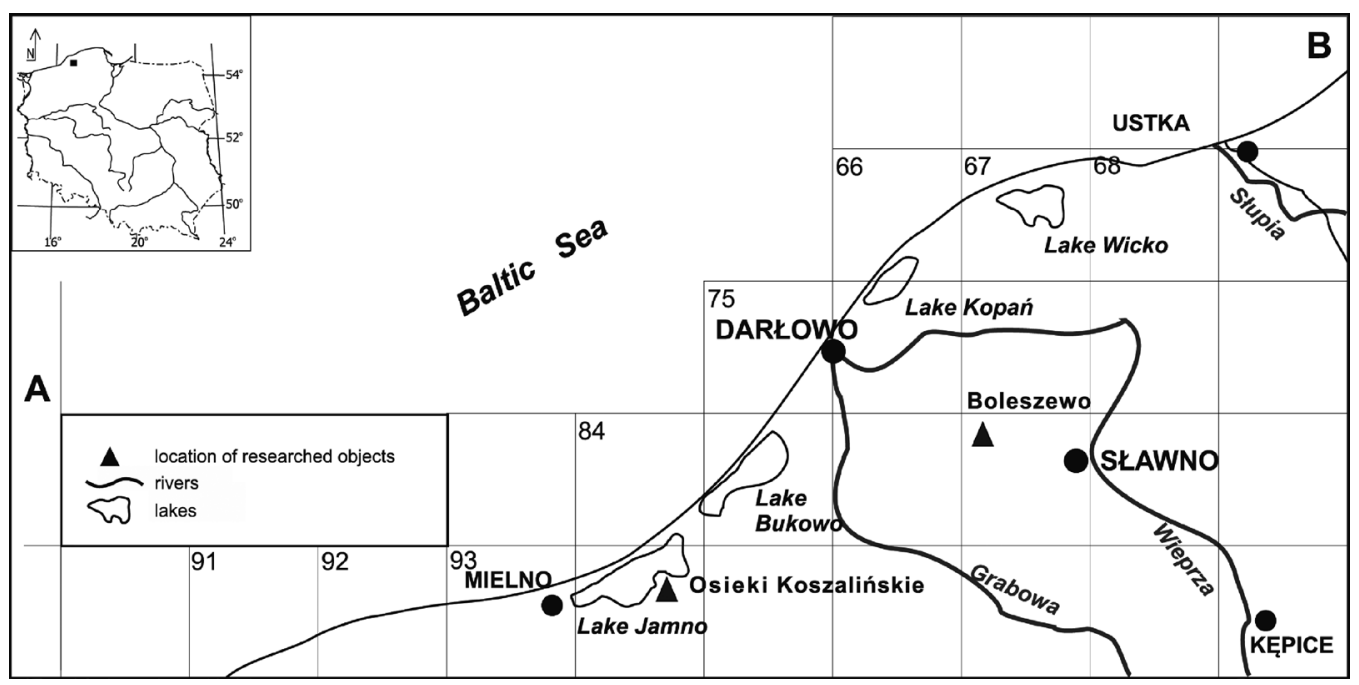

Fig. 1. Distribution of Geranium phaeum in the ATPOL grid of the Central Pomerania

The paper contains distribution, habitat conditions and phytosociological characteristics of the community Geranio phaei-Urticetum dioicae Hadač et al. (1969).

\section{Material and methods}

The studies of chorology of saum communities of selected midfield biotopes with participation of Geranium phaeum were carried at the Słowińskie Coast and Sławno Plain in the years 2011-2014. 16 phytosociological relevés were taken with application of BraunBlanqueta method. The classification and nomenclature of syntaxa was adopted after Ratyńska et al. (2010), the nomenclature of the vascular plants after Mirek et al. (2002) and bryophyta with the list of Ochyra et al. (2003).

All relevés were recorded in TURBOVEG data base, and subsequently were grouped, making introductory evaluation of similarities by means of TWINSPAN software (Hennekens \& Schaminée 2001). The set of 16 was analyzed to the $6^{\text {th }}$ level after previous transformation of 7 degree Braun-Blanquet scale into the order scale, adopting the following values: $r-1,+-2,1-3,2-5,3-7$, 4-8, 5-9. Phytosiociological relevés are classified by means of NCLAS software from SYNTAX 5.0 package (Podani 1993). Similarities between the relevés were calculated by means of Jaccard formula on a basis of presence or lack of compared species (Fig. 2).

The soil samples were taken from the layer of rhizosphere in direct vicinity of the root system of the examined plants, in order to establish chemical composition of the soil. The following characteristic features of the soil were determined: active acidity $\left(\mathrm{pH}_{\mathrm{H} 20}\right)$ and exchangeable acidity $\left(\mathrm{pH}_{\mathrm{KCl}}\right)$ by means of the potentiometric, total nitrogen - by the Kjeldahl's method, organic carbon - by the Tiurin's method (Bednarek et

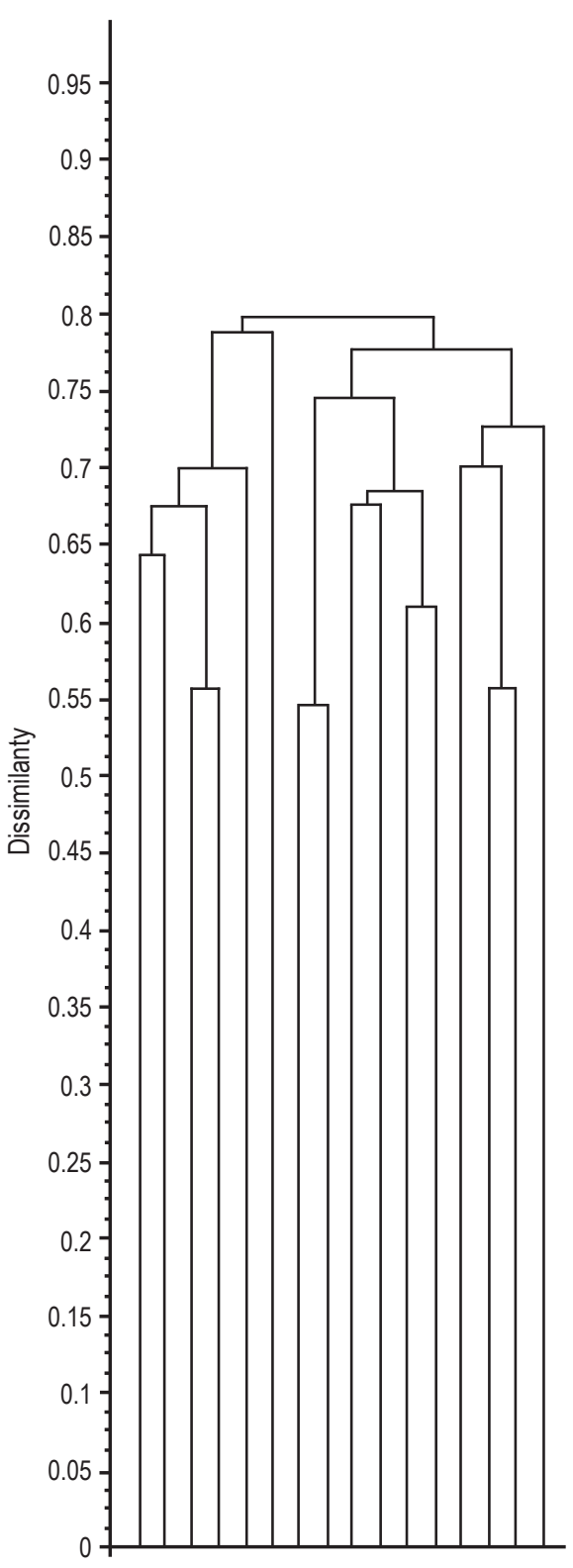

Fig. 2. Classification of Geranio phaei-Urticetum dioicae based on species composition in accordance with Jaccard's formula using the NCLAS program 
Table 2. Chemical parameters of soil

\begin{tabular}{|c|c|c|c|c|c|c|c|c|c|}
\hline \multirow{2}{*}{ Locality } & \multicolumn{2}{|c|}{$\mathrm{pH}$} & \multirow{2}{*}{ Humus (\%) } & \multirow{2}{*}{$\mathrm{C}(\%)$} & \multirow{2}{*}{ N (\%) } & \multirow{2}{*}{$\mathrm{P}(\%)$} & \multirow{2}{*}{$\mathrm{C} / \mathrm{N}$} & \multirow{2}{*}{$\mathrm{C} / \mathrm{P}$} & \multirow{2}{*}{$\mathrm{N} / \mathrm{P}$} \\
\hline & $\mathrm{H}_{2} \mathrm{O}$ & $\mathrm{KCl}$ & & & & & & & \\
\hline Boleszewo & 5.41 & 3.83 & 5.81 & 3.45 & 0.36 & 0.0198 & 13.87 & 190.50 & 14.45 \\
\hline $\begin{array}{l}\text { Osieki } \\
\text { Koszalińskie }\end{array}$ & 5.15 & 3.64 & 5.67 & 3.27 & 0.27 & 0.0172 & 13.48 & 190.30 & 14.31 \\
\hline
\end{tabular}

al. 2005), total phosphorus - by the molybdate method (Nowosielski 1974). In addition, the organic matter content in the examined substratum was determined.

\section{Results}

The phytosociological documentation of Geranio phaei-Urticetum dioicae phytocoenoses found in the 2 recorded localities consists of 16 relevés (Table $1-$ see page 00). 61 taxons in total were discovered in the community. In particular patches, there were from 16 to 25 species (average 21). The tree stand of the analyzed phytocenoses is dominated by Acer pseudoplatanus and Fraxinus excelsior. The layer of bushes is well developed. One can find Corylus avellana and Quercus robur in it. Attention is drawn by Sambucus nigra (III class of stability) - a taxon characteristic for SambucoSalicion relationship. Elder is indicator of anthropogenic communities of a high level of euthrophication of the soil (Wojterska 1990). The undergrowth is dominated by taxons of both syngenetic groups: Querco-Fagetea Br.-Bl. et Vlieg. 1937 and Fagetalia sylvaticae Pawł. in Pawł., Sokoł. et Wall 1928. This type is distinguished as the subassociation Geranio phaei-Urticetum dioicae allietosum ursini. Differential species are: Allium ursinum, Sanicula europaea and Asarum europaeum. A visible early spring aspect is a vital characteristic feature of the phytocenoses (relevés $3,7,11,15$ ), which falls for the brink of May. The following geophytes constitute physiognomy of the early spring patches: Anemone nemorosa and Ficaria verna. The early spring plants quickly yield to summer aspect species, of which: Poa nemoralis (V), and Aegopodium podagraria (V). In addition to the above mentioned Sambucus nigra, the presence of Artemisia vulgaris, Urtica dioica, Glechoma hederacea and Alliaria petiolata can indicate synanthropization of the analysed patches of the Geranio phaei-Urticetum dioicae. A numerous group (20 species) comprises accompanying and sporadic species (occuring only in I constancy class), of which the legally protected: Epipactis helleborine and Hedera helix. The moss layer is poorly developed. Only Plagiomnium undulatum is worth mentioning, which appeared in the III stability class with a relatively high coverage ratio (relevés 6-10). Participation of Atrichum undulatum moss characteristic for Querco-Fagetea, is scarce.

The soil examination showed its acidic reaction $(\mathrm{pH}=3.64-3.83)$, and it is quite well supplied with nitrogen, and a small quantity of the organic matter indicates that it is a mineral soil. Narrow relation of $\mathrm{C} / \mathrm{N}$ (13.48-13.87) represents good soil efficiency and good quality of the biotope, and the soil is sufficiently abundant with phosphorus (Table 2).

\section{Discussion}

The occurrence of this association, described as a community with Geranium phaeum was reported in the Polish part of the Tatra Mountains by Balcerkiewicz (1978) and then by Brzeg (1989). The first relevés of the association from the Góry Stołowe Mountains were made by Pender and Macicka-Pawlik (1996), who distinguished a 'community with Urtica dioica'. A similar 'community with Geranium phaeum' is known from Trzebnickie Hills (Pender \& Rybałtowska 1995). Swierkosz et al. (2002) reported the occurrence of the association in the southwest Poland. Five new subassociations of the Geranio phaei-Urticetum dioicae (G.-U. arrhenatheretosum elatioris, G.-U.typicum, G.-U.festucetosum giganteae, G.-U. senecionetosum fuchsii and G.-U. rumicetosum alpestris) have been distinguished on the basis of differing species composition.

The known range of the association is generally limited to mountain and submontane regions of Central Europe (the Tatras, Sudety Mountains and their foothills), with isolated localities on lowland - in northern Poland (Pomerania). In Poland it can be excepted mainly along the Carpathian-Sudetic arc and in adjacent areas (Zając 1996). Subassociation Geranio phaei-Urticetum dioicae allietosum ursini in Central Pomerania is new for Poland. 
Table 1. Geranio phaei-Urticetum dioicae Hadač et al. 1969 allietosum ursini Sobisz 2014 subass. nova. Nomenclature type: table 1 rel. 15 (orig.) holotypus hoc loco (Hadač et al. 1969; 215-217)

\begin{tabular}{|c|c|c|c|c|c|c|c|c|c|c|c|}
\hline Successive number of phytosociological relevé & 1 & 2 & 3 & 4 & 5 & 6 & 7 & 8 & 9 & 10 & 11 \\
\hline Phytosociological relevé area $\left[\mathrm{m}^{2}\right]$ & 15 & 12 & 12 & 10 & 15 & 10 & 15 & 10 & 10 & 20 & 12 \\
\hline \multirow[t]{2}{*}{ Date (day, month, year) } & 12.05 & 19.06 & 25.05 & 12.06 & 18.06 & 19.06 & 12.05 & 25.05 & 29.06 & 29.06 & 25.05 \\
\hline & 2011 & 2014 & 2014 & 2013 & 2011 & 2014 & 2011 & 2014 & 2013 & 2012 & 2014 \\
\hline Locality & OsK & Bo & Bo & Bo & Bo & OsK & OsK & OsK & OsK & OsK & OsK \\
\hline $\begin{array}{l}\text { Soil (mechanical compsition of A horison - 0-20 } \\
\mathrm{cm} \text { ) }\end{array}$ & org & org & org & pgm & org & org & $\mathrm{hbb}$ & org & org & org & pgm \\
\hline Density of shrub layer [\%] & 5 & 5 & 5 & 10 & 5 & & 2 & . & 2 & 2 & 2 \\
\hline Coverage of herb layer $[\%]$ & 90 & 70 & 100 & 95 & 80 & 90 & 100 & 95 & 90 & 100 & 95 \\
\hline \multirow{2}{*}{$\begin{array}{l}\text { Coverage of moos layer [\%] } \\
\text { Number of species in phytosociological relevé }\end{array}$} & 5 & . & 5 & 5 & . & 10 & 10 & 5 & 15 & 15 & 5 \\
\hline & 21 & 21 & 18 & 19 & 20 & 21 & 23 & 19 & 21 & 22 & 24 \\
\hline \multicolumn{12}{|l|}{ Ch. *D Ass. Geranio phaei-Urticetum dioicae } \\
\hline Geranium phaeum & 3.3 & 1.2 & +.2 & 1.2 & 2.2 & 2.2 & 1.2 & 1.1 & 3.3 & 2.2 & 1.1 \\
\hline *Melandrium rubrum & + & 1.1 & $\cdot$ & . & & 1.2 & 1.2 & . & $\cdot$ & 1.2 & + \\
\hline *Ranunculus lanuginosus & 1.2 & $\cdot$ & . & . & 1.2 & . & . & . & + & . & . \\
\hline \multicolumn{12}{|c|}{$\begin{array}{l}\text { ChAss. Geranio phaei-Urticetum dioicae allietosum } \\
\text { ursini }\end{array}$} \\
\hline Allium ursinum & 2.3 & 3.3 & 5.5 & 4.5 & 3.3 & 3.4 & 4.4 & 4.4 & 2.2 & 3.3 & 4.4 \\
\hline Sanicula europaea & + & $\cdot$ & $\cdot$ & . & $\cdot$ & + & + & $\cdot$ & $\cdot$ & 1.1 & + \\
\hline Asarum europaeum & $\cdot$ & 1.1 & · & . & +.2 & $\cdot$ & . & . & $\cdot$ & . & . \\
\hline \multicolumn{12}{|c|}{ I. ChO. Convolvuletalia sepium, ChAll. Petasition officinalis } \\
\hline Aegopodium podagraria & 1.2 & + & . & 1.1 & 1.1 & 1.1 & + & 1.1 & + & 1.2 & + \\
\hline Anthriscus sylvestris & 1.1 & . & +.2 & 1.1 & . & . & & 1.2 & . & & . \\
\hline Galium aparine & . & . & +.2 & . & . & . & 1.2 & . & . & +.2 & . \\
\hline Heracleum sphondylium & . & + & + & . & & $\cdot$ & + & . & + & $\cdot$ & + \\
\hline Alliaria petiolata & . & + & $\cdot$ & 1.1 & + & . & + & + & $\cdot$ & + & $\cdot$ \\
\hline Geranium robertianum & . & . & $\cdot$ & 1.2 & . & 1.1 & . & $\cdot$ & . & + & . \\
\hline Glechoma hederacea & . & . & . & $\cdot$ & + & . & + & $\cdot$ & $\cdot$ & . & $\cdot$ \\
\hline Viola odorata & . & . & . & . & . & + & . & . & + & . & + \\
\hline \multicolumn{12}{|l|}{ II. ChCl. Artemisietea vulgaris } \\
\hline Urtica dioica & 1.1 & 1.2 & + & 1.1 & 1.2 & 1.1 & 2.2 & 2.2 & 1.2 & 1.2 & 1.2 \\
\hline Artemisia vulgaris & 1.1 & + & 1.1 & . & + & $\cdot$ & . & + & + & 1.1 & + \\
\hline Myosoton aquaticum & 1.1 & . & + & . & + & . & + & . & + & . & . \\
\hline Equisetum arvense & . & +.2 & . & $\cdot$ & . & . & +.2 & . & . & + & . \\
\hline Cirsium arvense & + & $\cdot$ & . & + & $\cdot$ & $\cdot$ & . & $\cdot$ & . & . & $\cdot$ \\
\hline Melandrium album & $\cdot$ & + & $\cdot$ & . & . & . & . & + & 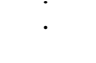 & $\dot{+}$ & + \\
\hline \multicolumn{12}{|l|}{ III. ChCl. Querco-Fagetea } \\
\hline Poa nemoralis & 1.2 & . & + & +.2 & + &.+ .2 & + & +.2 & +.2 & 1.1 & 1.2 \\
\hline Galeobdolon luteum & + & & + & . & . & + & 1.1 & + & + & + & $\cdot$ \\
\hline Acer pseudoplatanus $b$ & 1.2 & 1.2 & 1.2 & . & 1.2 & + & . & + & + & . & + \\
\hline Polygonatum multiflorum & . & + & + & . & + & +.2 & . & 1.2 & . & $\cdot$ & . \\
\hline Fraxinus excelsior $b$ & +.2 & . & $\cdot$ & 1.1 & $\cdot$ & . & . & . & 1.1 & & + \\
\hline Stachys sylvatica & . & + & . & $\cdot$ & 1.1 & $\cdot$ & . & & & 1.1 & . \\
\hline Milium effusum & . & . & . & . & . & . & + & 1.1 & . & . & + \\
\hline Ficaria verna & . & . & 1.1 & + & . & . & 1.1 & . & . & . & 1.2 \\
\hline Anemone nemorosa & . & . & + & & . & . & 1.2 & + & . & . & + \\
\hline Corylus avellana & . & & $\cdot$ & 1.1 & . & + & . & $\cdot$ & . & + & $\cdot$ \\
\hline \multicolumn{12}{|c|}{ IV. ChCl. Molinio-Arrhenatheretea, ChO. Arrhenatheretalia } \\
\hline Ranunculus repens & 1.2 & 1.2 & + & + & 1.2 & 1.2 & 1.2 & . & + & +.2 & + \\
\hline Poa trivialis & . & 1.1 & . & + & . & . & . & + & + & 1.2 & + \\
\hline Veronica chamaedrys & . & + & . & . & + & . & + & . & 1.1 & . & 1.2 \\
\hline Poa pratensis & . & + & . & $\cdot$ & . & $\cdot$ & . & . & . & +.2 & 1.1 \\
\hline Epilobium palustre & . & . & +.2 & + & $\cdot$ & 1.1 & . & $\cdot$ & $\cdot$ & . & $\cdot$ \\
\hline Dactylis glomerata & . & . & + & . & . & . & . & . & + & . & + \\
\hline Taraxacum officinale & . & . & . & . & . & . & + & . & . & . & $\cdot$ \\
\hline \multicolumn{12}{|l|}{ V. Accompanying species } \\
\hline Sambucus nigra & + & + & . & . & + & . & + & & + & . & + \\
\hline Plagiomnium undulatum & . & . & . & . & . & 1.2 & 1.2 & 1.2 & 2.2 & 2.2 & 1.2 \\
\hline Quercus robur b & . & + & . & . & . & . & + & . & + & . & + \\
\hline
\end{tabular}

Species occurring only in I constancy class: I. Calystegia sepium $1(+)$, Geum urbanum $9(+)$, Impatiens parviflora $4(+), 7(1.1), 9(+)$, Lamium maculatum 8, 15 (+); III. Atrichum undulatum 3, 6, 13 (1.2), Epipactis helleborine $6(+)$, Hedera helix $14(+)$, IV. Galium mollugo 10, $12(1.1)$, Poa pratensis 8, 11 $(+.2)$, Ranunculus acris 14, $16(+)$, Rumex acetosa 4, $15(+), 13(1.1)$, Sympytum officinale $5(+)$, V. Mentha arvensis $1(+)$, Mnium hornum 1, 4, $16(1.2)$, Scutellaria galericulata $2,5(+)$

Explanation: locality, Bo - Boleszewo, OsK - Osieki Koszalińskie; soil species, org - organic soil, pgm - heavy loamy sand 


\section{References}

\begin{tabular}{|c|c|c|c|c|c|c|}
\hline 12 & 13 & 14 & 15 & 16 & \multirow{5}{*}{\multicolumn{2}{|c|}{ Mean }} \\
\hline 12 & 25 & 25 & 20 & 10 & & \\
\hline 25.05 & 19.06 & 19.06 & 09.06 & 29.06 & & \\
\hline 2014 & 2014 & 2014 & 2012 & 2013 & & \\
\hline Bo & Bo & Bo & OsK & OsK & & \\
\hline pgm & pgm & org & org & org & \multirow{4}{*}{\multicolumn{2}{|c|}{20.06}} \\
\hline 2 & 2 & 2 & 5 & 5 & & \\
\hline 100 & 95 & 75 & 95 & 100 & & \\
\hline . & 5 & . & . & 5 & & \\
\hline 17 & 16 & 21 & 25 & 22 & $\mathrm{~S}$ & $\mathrm{D}$ \\
\hline \multirow[t]{2}{*}{+.2} & 1.2 & +.2 & 1.2 & 3.3 & V & 3248 \\
\hline & 1.2 & $\dot{r}$ & & . & III & $\begin{array}{l}144 \\
106\end{array}$ \\
\hline
\end{tabular}

BAlCERKIEwicz S. 1978. Vegetation of Polana Chochołowska (Chochołowska Clearing) in the West Tatras. In: T. Wojterski (ed.). Guide to the Polish International Excursion 1-20 June 1978. Uniwersytet im. Adama Mickiewicza w Poznaniu. Ser. Biologia 11: 355-381.

BRzEG A. 1989. A systematic survey of 'saum'-communities found and possibly occurring in Poland. Fragm. Flor. Geobot. 34: 385-425

Bednarek R., Dziadowiec H., Pokojska U. \& Prusinkiewicz Z. 2005. Badania ekologiczno-gleboznawcze. 344 pp. PWN, Warszawa.

Hadač E., BŔezina P., JežEk V., KubičKa J., Hadačová V. \&VondrÁČEK M. 1969. Die Pflanzengesellschaften des Tales 'Dolina Siedmich Prameńov' in der Belaer Tatra. Vegetacia ČSSR B2, Vydavatelstvo Slovenskej Akademie Vied, Bratislava.

\begin{tabular}{|c|c|c|c|c|c|c|}
\hline 5.5 & 3.3 & 3.3 & 4.4 & 2.2 & \multirow{2}{*}{$\begin{array}{l}\text { V } \\
\text { II }\end{array}$} & \multirow{2}{*}{$\begin{array}{c}4782 \\
62\end{array}$} \\
\hline & . & & . & + & & \\
\hline+ & . & + & . & . & II & 50 \\
\hline+ & 1.2 & . & 1.2 & + & V & 262 \\
\hline+ & 1.2 & & & . & III & 175 \\
\hline+.2 & . & 1.1 & + & + & III & 94 \\
\hline+ & . & . & . & + & III & 44 \\
\hline . & . & 1.1 & . & . & II & 87 \\
\hline & . & + & . &. & II & 75 \\
\hline+ & . & . & . & . & II & 25 \\
\hline . & . & . & + & . & II & 25 \\
\hline+ & 1.2 & 1.2 & 1.2 & 3.3 & $\mathrm{~V}$ & 816 \\
\hline & + & + & + & + & IV & 150 \\
\hline+ & . & & 1.1 & . & III & 250 \\
\hline 1.1 & . & 1.2 & . & 1.1 & III & 108 \\
\hline+ & . & 1.1 & . & + & II & 56 \\
\hline & . & . & . & + & II & 31 \\
\hline . & + & + & . & . & II & 25 \\
\hline+ & 2.2 & 2.2 & 1.2 & + & $\mathrm{V}$ & 400 \\
\hline . & 1.1 & $\cdot$ & + & + & IV & 112 \\
\hline . & & . & + & . & III & 156 \\
\hline . & +.2 & . & 1.2 & 1.1 & III & 131 \\
\hline+ & . & . & . & 1.1 & III & 119 \\
\hline . & . & + & $\cdot$ & . & II & 75 \\
\hline . & . & . & 1.2 & . & II & 75 \\
\hline . & . & . & + & . & II & 81 \\
\hline+ & . & . & + & . & II & 62 \\
\hline . & $\cdot$ & + & $\cdot$ & . & II & 50 \\
\hline.+ .2 & 1.2 & +.2 & +.2 & . & $\mathrm{V}$ & 237 \\
\hline . & +.2 & 1.2 & 1.2 & $\cdot$ & III & 156 \\
\hline . & . & . & + & +.2 & III & 94 \\
\hline . & $\cdot$ & . & . & 1.2 & II & 75 \\
\hline . & $\cdot$ & + & $\cdot$ & $\cdot$ & II & 50 \\
\hline . & . & . & + & +.2 & II & 31 \\
\hline . & + & . & + & + & II & 25 \\
\hline . & . & + & 1.2 & . & III & 75 \\
\hline . & . & . & . & . & II & 344 \\
\hline . & . & . & $\cdot$ & . & II & 25 \\
\hline
\end{tabular}

Hennekens S. M. \& Schaminée J. H. J. 2001. TURBOVEG, a comprehensive database management system for vegetation data. J. Veg. Sci. 12: 1-589.

Kondracki J. 2004. Geografia regionalna Polski. 441 pp. Wyd. Nauk. PWN, Warszawa.

Matuszkiewicz J. M. 1993. Krajobrazy roślinne i regiony geobotaniczne Polski. IGiPZ PAN Prace Geograf. 158: 5-107.

Matuszkiewicz W. 2001. Przewodnik do oznaczania zbiorowisk roślinnych Polski. In: J. B. FALIŃSKi (ed.). Vademecum Geobotanicum, 3, 537 pp. Wyd. Nauk. PWN, Warszawa.

Mirek Z., Piękoś-Mirkowa H., Zając A. \& Zając M. 2002. Flowering plants and pteridophytes of Poland. A checklist. In: Z. MireK (ed.). Biodiversity of Poland, 1, 442 pp. W. Szafer Institute of Botany, Polish Academy of Sciences, Kraków.

Mucina L. 1993. Galio-Urticetea. In: L. Mucina, G. Grabherr \& T. Ellmauer (eds), Die Pflanzengesellschaften Österreichs. Teil I. Anthropogene Vegetation, pp. 203-251. Gustav Fischer Verlag, Jena-Stuttgart-New York.

NowosielsKi O. 1974. Metody oznaczania potrzeb nawożenia. 720 pp. PWRiL, Warszawa.

Ochyra R., ŻarnowieC J. \& BednareK-Ochyra H. 2003. Census Catalogue of Polish Mosses. In: Z. Mirek (ed.). Biodiversity of Poland, 3, 372 pp. Polish Academy of Sciences, Institute of Botany, Kraków.

Pender K. \& RybaŁtowska Z. 1995. Vegetation of reservation 'Beech forest at Skarszyn'. Acta Univ. Wratislav., Prace Bot. 62: 79-99.

Pender K. \& Macicka-Pawlik T. 1996. Deciduous forests of the Lower subalpine zone in the midst of rocky-gates in the Pośna Valley of Stołowe Mountains. Acta Univ. Wratislav., Prace Bot. 70: 21-46.

Podani J. 1993. Syn-Tax - pc. Computer Programs for Multivare Data Analysis in Ecology and Systematics. Version 5.0. User's Giude. Scientia Publishing, Budapest, pp. 351.

Ratyńska H., Wojterska M. \& Brzeg A. 2010. Multimedialna encyklopedia zbiorowisk roślinnych Polski. 
Narodowy Fundusz Ochrony Środowiska i Gospodarki Wodnej w Warszawie, CD 1-2.

ŚwIERKosz K., DAJdok Z. \& SzCZĘŚNIAK E. 2002. The association Geranio phaei-Urticetum dioicae in southwest Poland. Polish Botanical Journal 47(1): 53-66.

Wojterska M. 1990. Mezofilne zbiorowiska zaroślowe Wielkopolski. PTPN, Prace Kom. Biol. 72: 3-125.

ZAJĄC A. 1978. Atlas of distribution of vascular plants in Poland (ATPOL). Taxon 27(5-6): 481-484.
ZAJAcC M. 1996. Mountain vascular plants in the Polish Lowlands. Polish Botanical Studies 11: 1-92.

ZAJĄC M. \& ZAJĄC A. 2009. The geographical elements of native flora of Poland. $94 \mathrm{pp}$. Edited by Laboratory of Computer Chorology, Institute of Botany, Jagiellonian University, Kraków. 